Brief Report

\title{
Antimicrobial Drug-Resistant Gram-Negative Saprophytic Bacteria Isolated from Ambient, Near-Shore Sediments of an Urbanized Estuary: Absence of $\beta$-Lactamase Drug-Resistance Genes
}

\author{
Charles F. Moritz ${ }^{1}$, Robert E. Snyder ${ }^{1}{ }^{\circledR}$, Lee W. Riley ${ }^{1}$, Devin W. Immke ${ }^{2}$ \\ and Ben K. Greenfield ${ }^{2, *(1)}$ \\ 1 School of Public Health, University of California, Berkeley, CA 94720, USA; cfmoritz@gmail.com (C.F.M.); \\ robert.snyder@berkeley.edu (R.E.S.); lwriley@berkeley.edu (L.W.R.) \\ 2 Department of Environmental Sciences, Southern Illinois University, Edwardsville, IL 62026, USA; \\ dimmke@siue.edu \\ * Correspondence: begreen@siue.edu
}

Received: 11 June 2020; Accepted: 7 July 2020; Published: 10 July 2020

\begin{abstract}
We assessed the prevalence of antimicrobial resistance and screened for clinically relevant $\beta$-lactamase resistance determinants in Gram-negative bacteria from a large urbanized estuary. In contrast to the broad literature documenting potentially hazardous resistance determinants near wastewater treatment discharge points and other local sources of aquatic pollution, we employed a probabilistic survey design to examine ambient, near-shore sediments. We plated environmental samples from 40 intertidal and shallow subtidal areas around San Francisco Bay (California, USA) on drug-supplemented MacConkey agar, and we tested isolates for antimicrobial resistance and presence of clinically relevant $\beta$-lactamase resistance determinants. Of the 74 isolates identified, the most frequently recovered taxa were Vibrio spp. (40\%), Shewanella spp. (36\%), Pseudomonas spp. (11\%), and Aeromonas spp. (4\%). Of the 55 isolates tested for antimicrobial resistance, the Vibrio spp. showed the most notable resistance profiles. Most (96\%) were resistant to ampicillin, and two isolates showed multidrug-resistant phenotypes: V. alginolyticus (cefotaxime, ampicillin, gentamicin, cefoxitin) and $V$. fluvialis (cefotaxime, ampicillin, cefoxitin). Targeted testing for class 1 integrons and presence of $\beta$-lactam-resistance gene variants TEM, SHV, OXA, CTX-M, and Klebsiella pneumonia carbapenemase (KPC) did not reveal any isolates harboring these resistance determinants. Thus, while drug-resistant, Gram-negative bacteria were recovered from ambient sediments, neither clinically relevant strains nor mobile $\beta$-lactam resistance determinants were found. This suggests that Gram-negative bacteria in this well-managed, urbanized estuary are unlikely to constitute a major human exposure hazard at this time.
\end{abstract}

Keywords: antibiotic resistance; aquatic contamination; probabilistic sampling; San Francisco Estuary; coast; Pseudomonas; Shewanella algae; Vibrio parahaemolyticus

\section{Introduction}

The development of antimicrobial resistance in Gram-negative bacteria is a serious and growing global concern. Anthropogenic selection of highly resistant bacteria is driven by the overuse of antimicrobial agents in healthcare and agriculture as well as their mismanagement during waste disposal [1-6]. This selective process has dramatically affected global health; drug-resistant infections have become widespread globally [7-10] and were recently estimated at over 2 million infections in the United States annually [11]. Environmental and saprophytic bacteria are important as 
indicators and reservoirs of antibiotic resistance determinants that may be shared by human bacterial pathogens [12-19].

The $\beta$-lactams are currently the most widely used class of antimicrobial agents for treatment of bacterial infections in humans [20]. Gram-negative bacteria (GNB) have evolved to develop resistance to $\beta$-lactams by producing $\beta$-lactamase enzymes that hydrolyze $\beta$-lactams. Indeed, 2771 unique $\beta$-lactamase enzymes were discovered as of 2018 [21]. Extended-spectrum $\beta$-lactamases (ESBLs) such as TEM-, SHV-, OXA-, and CTX-M-type $\beta$-lactamases have become widespread in clinical and environmental settings, threatening the utility of broader-spectrum $\beta$-lactam drugs [21,22]. More recently, resistance to carbapenem drugs in GNB of the family Enterobacteriaceae, through production of Klebsiella pneumonia carbapenemases (KPCs), has become an imminent public health threat $[9,14,23,24]$. Genes encoding these $\beta$-lactamases are often located on mobile genetic elements that mediate their transfer between bacteria of the same or different species. This mechanism may contribute to dissemination of resistance determinants from the natural environment to healthcare settings [25].

Coastal and river waters located in populated areas with limited or overextended water and sanitation infrastructure harbor high rates of drug-resistant bacteria $[6,17,26,27]$, but the extent to which this is true in areas with reliable secondary and tertiary wastewater treatment facilities is not as well characterized. San Francisco Bay (CA, USA) is located in a highly populated and urbanized region with extensive wastewater treatment infrastructure [28,29]. San Francisco Bay also has a legacy of environmental contamination that has resulted in elevated concentrations of a broad range of pollutants [30]. This includes fecal contamination observed at ponds managed as bird habitats and sloughs [31], and occasionally at swimming beaches [32,33]. Here, we assessed the prevalence of antimicrobial resistance in GNB in near-shore sediments collected from San Francisco Bay, an estuarine environment with ambient urban pollution. We determined resistant strain taxa and tested resistant isolates for class 1 integrons and presence of $\beta$-lactam-resistance gene variants TEM, SHV, OXA, CTX-M, and KPC. To our knowledge, this is the first probabilistic spatial survey of an estuary's sediment for clinically relevant genetic resistance elements in GNB.

\section{Results}

None of the 40 collection sites were immediately adjacent to treated wastewater discharge locations (Figure 1). Bacteria colonies grew on unsupplemented plates from all 40 sites, but none presented as positive for lactose utilization, indicating that lac+ colonies (e.g., Escherichia coli) were absent from all samples. From the 40 sites, bacterial isolates that grew in the presence of ampicillin, gentamicin, imipenem, and cefotaxime were found at 34 (85\%), $27(67.5 \%), 15(37.5 \%)$, and $9(22.5 \%)$ sites, respectively (Table 1). From the initial antibiotic-containing MacConkey agar plates, 174 isolates were obtained and subjected to further analyses. Bacteria isolated from plates containing ampicillin were the most prevalent ( 87 isolates from 32 sites), followed by gentamicin (39 isolates from 13 sites), imipenem ( 37 from 15 sites), and cefotaxime (11 isolates from 8 sites) (Table 1). 


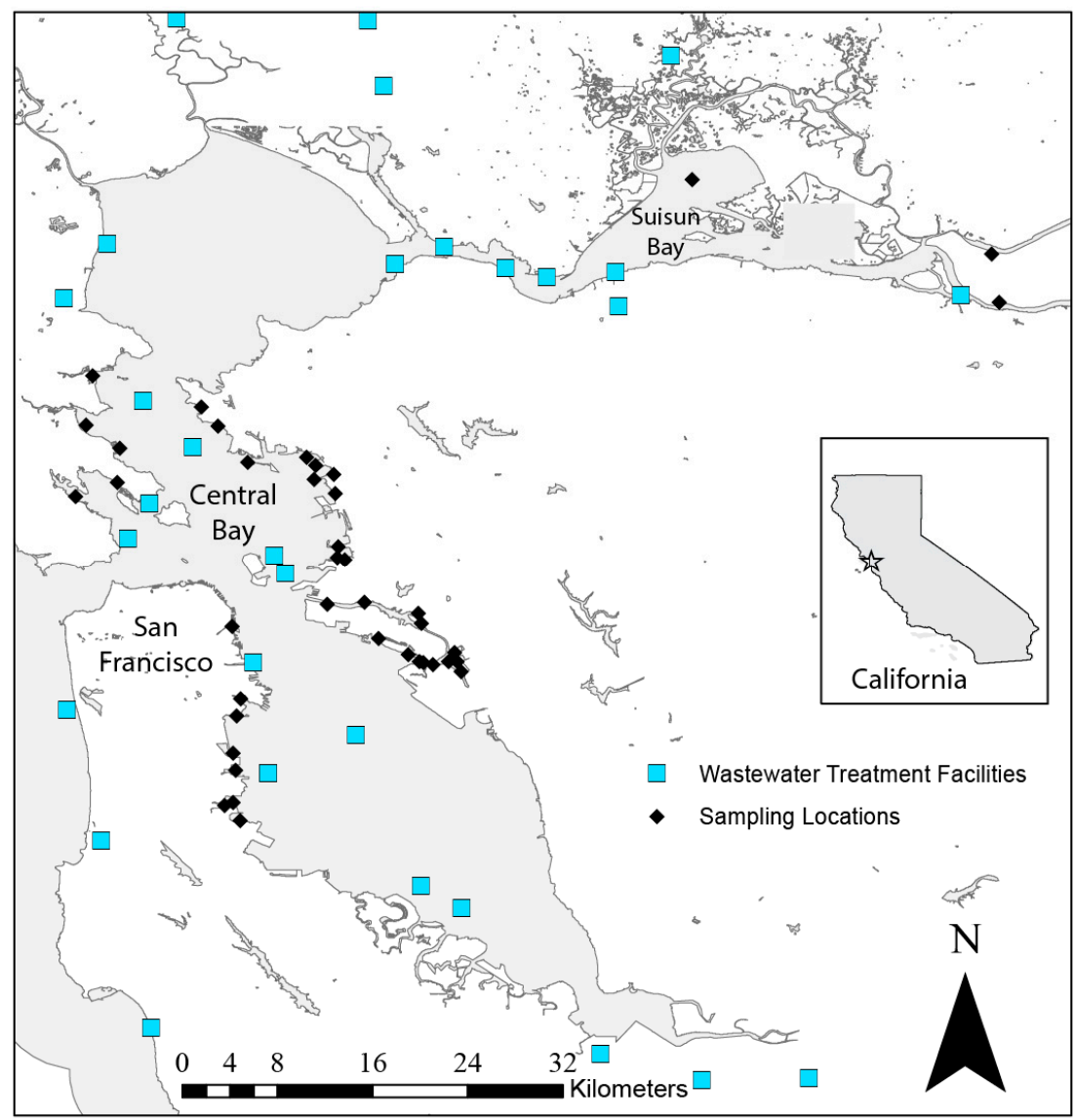

Figure 1. San Francisco Bay. Black diamonds $(\downarrow)$ indicate sediment collection location. Light blue squares $(\square)$ indicate wastewater treatment discharge locations in the region. Inset: Location within California, USA.

Table 1. Number of morphologically distinct bacterial colonies isolated from estuarine sediments in the San Francisco Bay Area, 2015, by antibiotic used for screening.

\begin{tabular}{ccccc}
\hline Antibiotic $^{\text {a }}$ & $\begin{array}{c}\text { Sites with Growth } \\
(\mathbf{N}, \mathbf{\%})\end{array}$ & $\mathbf{C F U / g} \mathbf{b}$ & $\begin{array}{c}\text { Sites with Isolates } \\
\text { Obtained (N) }\end{array}$ & $\begin{array}{c}\text { Morphologically } \\
\text { Distinct Isolates } \\
\text { Obtained (N) }\end{array}$ \\
\hline No antimicrobial agent & $40(100 \%)$ & 3513 & & \\
Ampicillin & $34(85 \%)$ & 1280 & 32 & 87 \\
Cefotaxime & $9(22.5 \%)$ & 16 & 8 & 37 \\
Imipenem & $15(37.5 \%)$ & 106 & 15 & 39 \\
Gentamicin & $27(67.5 \%)$ & 196 & 13 & 37 \\
\hline
\end{tabular}

${ }^{a}$ Concentrations of antibiotic embedded in MacConkey agar plates: ampicillin, $16 \mu \mathrm{g} \mathrm{mL}^{-1}$; imipenem, $1 \mu \mathrm{g} \mathrm{mL}{ }^{-1}$; cefotaxime, $1 \mu \mathrm{g} \mathrm{mL}^{-1}$; and gentamicin, $10 \mu \mathrm{g} \mathrm{mL}^{-1}$. ${ }^{\mathrm{b}}$ Colonies were counted on MacConkey agar plates and multiplied by the dilution factor to approximate the number of $\mathrm{CFU} / \mathrm{g}$ sediment in each sediment sample. ${ }^{\mathrm{c}}$ Number of bacteria isolated from all antibiotic screening plates.

Seventy-two different Gram-negative bacterial isolates were identified by their $16 \mathrm{~S}$ rRNA sequences. They included 1 Acinetobacter sp. (1.4\%), 3 Aeromonas spp. (4.2\%), 1 Castellaniella sp. (1.4\%), 1 Gallaecimonas sp. (1.4\%), 8 Pseudomonas spp. (11\%), 1 Rhizobium sp. (1.4\%), 26 Shewanella spp. (36.1\%), 2 Stenotrophomonas spp. (2.8\%), and 29 Vibrio spp. (40.3\%) (Table 2). Fifty-three of the identified isolates were tested for their susceptibility to seven different antimicrobial agents (Table 3). Among 23 Vibrio spp. isolates, $22(95.7 \%)$ were resistant to ampicillin. This included one isolate (V. alginolylticus) resistant to ampicillin and gentamicin and two isolates (8.7\%) that displayed multidrug-resistant (MDR) phenotypes: V. alginolyticus (cefotaxime (CTX), ampicillin (AMP), gentamicin (GEN), and 
cefoxitin (FOX)) and $V$. fluvialis (CTX, AMP, amoxicillin-clavulanic acid (AMC), FOX). Among the 26 Shewanella spp. isolates, none were resistant to any of the drugs tested, except for three isolates that had intermediate resistance to imipenem. Due to a lack of Clinical and Library Standards Institute (CLSI) interpretive guidelines for the disc-diffusion test, we were unable to test Pseudomonas spp. isolates for phenotypic resistance.

Table 2. Identity of bacterial species recovered from San Francisco Bay sediment, 2015, by antibiotic used to select for resistance in initial MacConkey agar plate.

\begin{tabular}{|c|c|c|c|c|c|}
\hline Antibiotic & Species & Isolates (N) & Antibiotic & Species & Isolates $(\mathbf{N})$ \\
\hline \multirow{5}{*}{$\begin{array}{l}\text { Ampicillin } \\
\left(16 \mu \mathrm{gL}^{-1}\right)\end{array}$} & Total & 21 & \multirow{12}{*}{$\begin{array}{l}\text { Imipenem } \\
\left(1 \mu \mathrm{g} \mathrm{mL}^{-1}\right)\end{array}$} & Total & 35 \\
\hline & Vibrio alginolyticus & 6 & & Aeromonas australiensis & 1 \\
\hline & Vibrio parahaemolyticus & 6 & & Aeromonas hydrophila & 1 \\
\hline & Vibrio alginolyticus/parahaemolyticus ${ }^{\text {a }}$ & 7 & & Aeromonas veronii & 1 \\
\hline & Vibrio alginolyticus/azureus ${ }^{\text {a }}$ & 2 & & Castellaniella defragrans & 1 \\
\hline \multirow{8}{*}{$\begin{array}{l}\text { Cefotaxime } \\
\left(1 \mu \mathrm{g} \mathrm{mL} \mathrm{m}^{-1}\right)\end{array}$} & Total & 11 & & Pseudomonas sp. ${ }^{\mathrm{b}}$ & 1 \\
\hline & Acinetobacter venetianus & 1 & & Shewanella algae & 7 \\
\hline & Gallaecimonas xiamenensis & 1 & & Shewanella algae/haliotis a & 11 \\
\hline & Pseudomonas fluorescens & 2 & & Shewanella loihica & 8 \\
\hline & Pseudomonas oleovorans & 1 & & $\begin{array}{c}\text { Stenotrophomonas } \\
\text { maltophilia }\end{array}$ & 2 \\
\hline & Pseudomonas putida & 3 & & Vibrio diazotrophicus & 1 \\
\hline & Pseudomonas stutzeri & 1 & & Vibrio fluvialis & 1 \\
\hline & $\begin{array}{l}\text { Rhizobium sp. }{ }^{\mathrm{b}} \\
\text { Vibrio fluvialis }\end{array}$ & $\begin{array}{l}1 \\
1\end{array}$ & $\begin{array}{l}\text { Gentamicin } \\
\left(10 \mu \mathrm{g} \mathrm{mL}^{-1}\right)\end{array}$ & Vibrio parahaemolyticus & 5 \\
\hline
\end{tabular}

${ }^{a}$ Unable to discriminate between two species after $16 \mathrm{~S}$ sequence analysis. ${ }^{\mathrm{b}}$ Species not determined.

Table 3. Species and antibiotic resistance profiles of bacteria recovered from estuarine sediments in San Francisco Bay, 2015, from drug-supplemented media. Plate: Drug supplementation on plate (see Methods).

\begin{tabular}{|c|c|c|c|c|}
\hline Species & $\begin{array}{c}\text { Isolates } \\
\text { (N) }\end{array}$ & Plate & $\begin{array}{c}\text { Resistance (Disc } \\
\text { Diffusion) }^{a}\end{array}$ & $\begin{array}{c}\text { Intermediate } \\
\text { Resistance (Disc } \\
\text { Diffusion) }^{a}\end{array}$ \\
\hline Acinetobacter venetianus & 1 & CTX & CTX & \\
\hline Aeromonas australiensis & 1 & IPM & AMC & \\
\hline Aeromonas hydrophila & 1 & IPM & FOX & AMC \\
\hline Aeromonas veronii & 1 & IPM & None & \\
\hline Shewanella algae & 4 & IPM & None & \\
\hline Shewanella algae & 3 & IPM & & IPM \\
\hline Shewanella algae/halitosis $\mathrm{b}$ & 11 & IPM & None & \\
\hline Shewanella loihica & 8 & IPM & None & \\
\hline Vibrio alginolyticus & 3 & AMP & AMP & \\
\hline Vibrio alginolyticus & 1 & AMP & $\begin{array}{l}\text { AMP, } \text { CTX, GEN, } \\
\text { FOX }\end{array}$ & \\
\hline Vibrio alginolyticus & 1 & AMP & AMP, GEN & \\
\hline $\begin{array}{c}\text { Vibrio } \\
\text { alginolyticus/parahaemolyticus b }\end{array}$ & 4 & AMP & AMP & \\
\hline Vibrio diazotrophicus & 1 & IPM & None & \\
\hline Vibrio fluvialis & 1 & CTX & AMP, CTX, AMC & FOX \\
\hline Vibrio fluvialis & 1 & IPM & AMP & AMC \\
\hline Vibrio parahaemolyticus & 5 & AMP & AMP & \\
\hline Vibrio parahaemolyticus & 1 & AMP & AMP & CIP \\
\hline Vibrio parahaemolyticus & 5 & GEN & AMP & \\
\hline
\end{tabular}

a AMP, ampicillin; CTX, cefotaxime; IPM, imipenem; AMC, amoxicillin-clavulanic acid; GEN, gentamicin; FOX, cefoxitin; CIP, ciprofloxacin. ${ }^{\mathrm{b}}$ Unable to discriminate between two species after $16 \mathrm{~S}$ sequence analysis.

Of the 174 isolates that grew on drug-supplemented MacConkey agar plates, 174, 37, 98, and 11 isolates were tested for the presence of genes that encode class 1 integrons, carbapenemase (KPC), 
ESBLs (TEM, OXA, SHV), and CTX-M-type ESBLs, respectively. All PCR reactions were negative for these resistance genes.

\section{Discussion}

From 40 near-shore sites in the Bay Area, we isolated 18 distinct species of Gram-negative saprophytic bacteria (Table 2) on drug-supplemented plates. Although no recognized pathogenic GNB species were identified, many culturable isolates exhibited resistance to clinically used antimicrobial agents. Most studies assessing the presence of drug resistance in environmental bacteria thoroughly characterize a small number of sites, typically near known point-source pollutant effluent locations $[1,17,18,26,34,35]$. There have also been some comparative surveys across multiple water bodies $[6,15]$. In contrast to these designs, our sampling scheme extensively sampled a near-shore environment under ambient urban influence. In particular, our sampling sites were probabilistically chosen from intertidal and shallow subtidal areas around a large, urbanized estuary [36]. In this regionally representative sampling program, environmental bacteria were successfully isolated from every sampling site.

While species of several genera identified here (e.g., Aeromonas spp., Pseudomonas spp., Shewanella spp., and Vibrio spp.) have been described as opportunistic pathogens, they are all commonly found in marine-sediment environments, and their presence is rarely considered a public health risk [37-41]. Nevertheless, the genera Aeromonas, Pseudomonas, and Shewanella have been implicated as natural progenitors of, and reservoirs for, resistance genes such as CTX-M-, GES-, VIM-, and OXA-type ESBLs and carbapenemases that can be horizontally transferred into more pathogenic bacteria [25,42-44]. High rates of ampicillin resistance in Vibrio spp. have been well documented [45], consistent with the resistance rate of $96 \%$ found in this study. We also found five Vibrio isolates (22\%) that displayed other resistance phenotypes. However, none of these harbored any of the common clinical resistance genes we tested for, including TEM, SHV, and OXA. The majority of bacteria that grew under selective pressure for imipenem resistance were Shewanella spp. (26 isolates; $74 \%$ ); however, only three of these Shewanella spp. isolates (12\%) exhibited intermediate resistance to carbapenems, with none being resistant. Shewanella spp. have been reported elsewhere to have reduced susceptibility to carbapenems, and the genus has also been identified as a natural progenitor of several OXA-type carbapenemases [42,46], yet none were found in our study.

Due to an absence of CLSI guidelines for nonclinically relevant bacteria, the antimicrobial susceptibilities of the isolated Pseudomonas spp. (including Pseudomonas fluorescens, P. oleovorans, P. putida, and P. stutzeri) were not tested by the disc-diffusion method. However, further investigation into the antimicrobial resistance profiles and genes for these isolates is warranted because the genus has been observed to harbor genes that mediate resistance to antimicrobial agents. Environmentally occurring Pseudomonas spp. harboring carbapenemases and ESBLs, namely VIM, IMP, and several CTX-M variants, have been widely reported in the past decade $[19,43,47,48]$. The CTX-M variants that we tested for in isolated Pseudomonas spp. were those known to be circulating in the region and were previously found in P. putida and P. teessidea in retail spinach [16].

A notable result of this study was the absence of drug-resistant bacteria from the Enterobacteriaceae family as well as the absence of fecal indicator bacteria [19]. A number of similar studies found an abundance of such bacteria, but these studies were conducted in water bodies and under conditions that would suggest a priori high levels of fecal contamination $[4,17,40]$. The frequency of fecal contamination in San Francisco Bay beaches is variable but generally low, and Bay beaches are typically safe for human recreation, with most beaches considered safe for swimming, especially during dry weather [32,33]. Carbapenem-resistant Enterobacteriaceae (CRE) present serious public health risk, and they were a major target of the present study; however, no such bacteria were isolated from the areas we tested.

There were several limitations in this study. Certain species may have been inhibited by the stress of the freeze-thaw step in combination with drug-supplemented MacConkey agar. Further, the techniques described here were culture-dependent, and PCR analysis was restricted to class 1 
integrons and $\beta$-lactam resistance, which precluded the identification of other integrons or potentially relevant resistance mechanisms. Nevertheless, given the clinical importance of class 1 integrons [49], the observation of other associated resistance genes such as trimethoprim-sulfa or aminoglycoside would be unlikely in their absence. That said, the observed absence of $\beta$-lactam resistance mechanisms does not consider the full range of possible resistance genes. In the future, metagenomic study of DNA present in San Francisco Bay sediment samples or other whole-resistome screening approaches could reveal other clinically or environmentally relevant mechanisms [6,35].

Importantly, this study probabilistically sampled from 37 of the sites [36] in order to assess for regional patterns, rather than focusing only on areas of anthropogenic contamination. Studies that target wastewater treatment plants, hospital effluents, or animal livestock runoff could yield a higher prevalence of antimicrobial resistance among clinically relevant bacteria. In our study, the absence of clinically relevant drug-resistant GNB harboring $\beta$-lactamases and related resistance determinants suggests that GNB from ambient sediments in this well-managed, urbanized estuary may not constitute a major human exposure hazard at this time. These findings may be related to secondary and tertiary treatment operations and control measures for all wastewaters that drain into the Bay [28], in combination with the large dilution factor due to tidal exchange, resulting in low ambient sediment bacterial pollution in this estuary. These hypotheses could be tested in the future by evaluating resistance profiles and mechanisms in bacteria obtained from point sources and adjacent locations, including wastewater discharge effluents $[1,4,18,34,35]$. However, our study represents just one line of evidence, and routine water monitoring does periodically detect elevated fecal coliforms at some beaches [32]. Resistance to $\beta$-lactams continues to spread globally in GNB while, in parallel, novel resistance genes in environmental bacteria continue to be described. Therefore, routine environmental surveillance is needed to assess for the presence of potentially harmful bacteria or drug-resistance genes.

\section{Materials and Methods}

\subsection{Sample Collection and Processing}

Thirty-seven near-shore sites were sampled from Central San Francisco Bay (Central Bay), and three from Suisun Bay, both sub-basins of San Francisco Bay (Figure 1). The Central Bay sites were selected using a generalized random-tessellation stratified methodology, which is a probabilistic but spatially balanced method developed to identify locations for the sampling of natural resources [50]. The Suisun Bay samples were convenience samples, employing collection methods identical to those of the Central Bay sites. Although all sites were near-shore, a variety of habitats were included in the spatial sample, including both open water and narrow channels, sites adjacent to densely populated areas (e.g., San Francisco, CA, USA; Oakland, CA, USA), and sites proximate to more sparsely populated areas (e.g., Marin County and Suisun Bay) (Figure 1) [36].

Coastal Conservation and Research (Moss Landing, CA, USA) sampled all sites between 27 July and 14 September, 2015, as part of the Regional Monitoring Program (RMP)'s Bay Margins Sediment Study [51,52]. Sediments were collected by boat, with personnel using a modified VanVeen grab $\left(0.1 \mathrm{~m}^{2}\right.$ sampling area), from which $15 \mathrm{~mL}$ of surface sediment was scraped into a 50-mL conical tube (Fischer Scientific, Hampton, NH, USA). Sediment samples were combined with $20 \mathrm{~mL}$ of a preservative solution $\left(15 \%\right.$ glycerol in phosphate-buffered saline solution, PBS) and stored on dry ice $\left(-78.5^{\circ} \mathrm{C}\right)$ for transportation to the laboratory, after which they were immediately stored at $-20^{\circ} \mathrm{C}$ until analysis.

\subsection{Gram-Negative Bacteria Isolation}

Samples were thawed prior to analysis and diluted 10-fold with PBS. We selected for bacteria with reduced drug susceptibility by incubating $100 \mu \mathrm{L}$ of this PBS-sediment solution on MacConkey agar (Difco Laboratories Inc., Detroit, MI, USA), supplemented with one of four antibiotics: ampicillin $\left(16 \mu \mathrm{g} \mathrm{mL} L^{-1}\right)$, gentamicin $\left(10 \mu \mathrm{g} \mathrm{mL}^{-1}\right)$, imipenem $\left(1 \mu \mathrm{g} \mathrm{mL} L^{-1}\right)$, or cefotaxime $\left(1 \mu \mathrm{g} \mathrm{mL}^{-1}\right)$. An 
additional plate without any antibiotics was used to assess baseline growth. Plates were incubated at $37^{\circ} \mathrm{C}$ for $24 \mathrm{~h}$ and assessed for growth. In the absence of any growth at this stage, plates were incubated for another $24 \mathrm{~h}$. All plates were examined for well-formed colonies, and the total number of CFUs was recorded (Table 1). Up to four colonies were selected from each antibiotic plate for further analysis. In an attempt to increase the diversity of species isolated, we tried to choose morphologically distinct isolates within a plate, based on visual observation. The selected colonies were streaked for isolation on MacConkey agar and incubated again at $37^{\circ} \mathrm{C}$ for $24 \mathrm{~h}$. An isolated colony from each of these plates was then streaked for isolation on Luria-Bertani (LB) agar (Difco Laboratories Inc., Detroit, MI, USA) and incubated at $37^{\circ} \mathrm{C}$ for $24 \mathrm{~h}$. Finally, an isolated colony from each LB plate was subcultured in $4 \mathrm{~mL}$ of LB broth (Difco Laboratories Inc., Detroit, MI, USA) at $37^{\circ} \mathrm{C}$ for $24 \mathrm{~h}$. A $1-\mathrm{mL}$ aliquot of this culture was saved in a $15 \%$ glycerol stock, and a separate $1-\mathrm{mL}$ aliquot was used to extract DNA: Bacteria were concentrated by centrifugation (60 s, 14,000 RPM), resuspended in water, and placed in a boiling water bath for $10 \mathrm{~min}$; excess cell debris was collected by centrifugation ( $30 \mathrm{~s}$, 14,000 RPM); and the supernatant containing the DNA was pipetted to a separate tube and stored at $-20{ }^{\circ} \mathrm{C}$ before analysis.

\subsection{Bacterial Species Identification and Drug-Susceptibility Tests}

Bacteria were identified by $16 \mathrm{~S}$ rRNA sequencing. PCR was first carried out with the primers 16s8F/16s806R $18\left(94{ }^{\circ} \mathrm{C}\right.$ for $5 \mathrm{~min}$, then 30 cycles of $94{ }^{\circ} \mathrm{C}$ for $30 \mathrm{~s}, 62^{\circ} \mathrm{C}$ for $30 \mathrm{~s}$, and $72{ }^{\circ} \mathrm{C}$ for $90 \mathrm{~s}$ ) as previously described by Raphael et al. [16]. The amplified DNA products (approximately $800 \mathrm{bp}$ ) were sequenced on an Applied Biosystems 3730 DNA analyzer (Applied Biosystems, Foster City, CA, USA) at the University of California, Berkeley, DNA Sequencing Facility. Antimicrobial susceptibility profiles were assessed with a disc-diffusion assay according to the CLSI interpretive guidelines [53].

All isolates were tested for the presence of genes encoding class 1 integrons by PCR following a procedure previously described by Raphael et al. [16]. Class 1 integrons were chosen because of their clinical relevance and prevalence and widespread distribution in Gram-negative bacteria, both globally [49] and in the San Francisco Bay region [10]. All isolates obtained from MacConkey agar plates containing ampicillin $(16 \mu \mathrm{g} \mathrm{mL}-1)$, and those that were resistant to ampicillin by the disc-diffusion test, were examined by PCR for the presence of the following extended spectrum $\beta$-lactamase variants: TEM (including TEM-1 and TEM-2), SHV (including SHV-1), and OXA (OXA-1, OXA-4, and OXA-30). For this, we employed multiplex primers and reaction conditions described by Dallenne et al. [54]. Isolates obtained from MacConkey agar plates containing cefotaxime $(1 \mu \mathrm{g}$ $\mathrm{mL}^{-1}$ ), and those that were resistant to cefotaxime by the disc-diffusion test, were tested for CTX-M genes using a set of multiplex primers and conditions for CTX-M variants (CTX-M-1, CTX-M-3, and CTX-M-15) as described by Adams-Sapper et al. [22]. Isolates obtained from plates supplemented with imipenem were tested for the variants of the carbapenemase gene KPC using primers and conditions described by Dallenne et al. [54]. Additionally, all bacteria with multidrug-resistant phenotypes were tested for variants of all the above-mentioned genes: TEM, SHV, OXA, CTX-M, and KPC.

Author Contributions: Conceptualization, L.W.R. and B.K.G.; methodology, C.F.M., R.E.S., L.W.R., and B.K.G.; formal analysis, C.F.M. and B.K.G.; investigation, C.F.M.; resources, L.W.R.; data curation, C.F.M. and B.K.G.; writing-original draft preparation, C.F.M.; writing—review and editing, C.F.M., R.E.S., L.W.R., D.W.I., and B.K.G.; supervision, L.W.R. and B.K.G.; and project administration, C.F.M., D.W.I., and B.F.G. All authors have read and agreed to the published version of the manuscript.

Funding: This research received no external funding.

Acknowledgments: Sediment samples were provided by Russell Fairey and Marco Sigala of Moss Landing Marine Laboratories as part of the Regional Monitoring Program for Water Quality in San Francisco Bay. We thank Don Yee of the San Francisco Estuary Institute as well as Sheila Adams-Sapper and Nicole Tarlton from UC Berkeley for their valuable study guidance, in addition to Megan Danielson for her assistance with Figure 1.

Conflicts of Interest: The authors declare no conflict of interest. 


\section{References}

1. Korzeniewska, E.; Harnisz, M. Extended-Spectrum Beta-Lactamase (ESBL)-Positive Enterobacteriaceae in Municipal Sewage and Their Emission to the Environment. J. Environ. Manage. 2013, 128, 904-911. [CrossRef] [PubMed]

2. Goñi-Urriza, M.; Capdepuy, M.; Arpin, C.; Raymond, N.; Pierre Caumette, C.Q. Impact of an Urban Effluent on Antibiotic Resistance of Riverine Enterobacteriaceae and Aeromonas Spp. Appl. Environ. Microbiol. 2000, 66, 125-132. [CrossRef] [PubMed]

3. Tello, A.; Austin, B.; Telfer, T.C. Selective Pressure of Antibiotic Pollution on Bacteria of Importance to Public Health. Environ. Health Perspect. 2012, 120, 1100-1106. [CrossRef] [PubMed]

4. Amos, G.C.A.; Hawkey, P.M.; Gaze, W.H.; Wellington, E.M. Waste Water Effluent Contributes to the Dissemination of CTX-M-15 in the Natural Environment. J. Antimicrob. Chemother. 2014, 69, 1785-1791. [CrossRef]

5. $\quad$ Fleming-Dutra, K.E.; Hersh, A.L.; Shapiro, D.J.; Bartoces, M.; Enns, E.A.; File, T.M.; Finkelstein, J.A.; Gerber, J.S.; Hyun, D.Y.; Linder, J.A.; et al. Prevalence of Inappropriate Antibiotic Prescriptions among Us Ambulatory Care Visits, 2010-2011. JAMA-J. Am. Med. Assoc. 2016, 315, 1864-1873. [CrossRef]

6. Zhu, Y.G.; Zhao, Y.; Li, B.; Huang, C.L.; Zhang, S.Y.; Yu, S.; Chen, Y.S.; Zhang, T.; Gillings, M.R.; Su, J.Q. Continental-Scale Pollution of Estuaries with Antibiotic Resistance Genes. Nat. Microbiol. 2017, 2, 16270. [CrossRef]

7. Laxminarayan, R.; Duse, A.; Wattal, C.; Zaidi, A.K.M.; Wertheim, H.F.L.; Sumpradit, N.; Vlieghe, E.; Hara, G.L.; Gould, I.M.; Goossens, H.; et al. Antibiotic Resistance-the Need for Global Solutions. Lancet Infect. Dis. 2013, 1057-1098. [CrossRef]

8. Nagvekar, V.; Sawant, S.; Amey, S. Prevalence of Multi Drug Resistant Gram-Negative Bacteria Cases at Admission in Multispecialty Hospital. J. Glob. Antimicrob. Resist. 2020. [CrossRef]

9. Fasciana, T.; Gentile, B.; Aquilina, M.; Ciammaruconi, A.; Mascarella, C.; Anselmo, A.; Fortunato, A.; Fillo, S.; Petralito, G.; Lista, F.; et al. Co-Existence of Virulence Factors and Antibiotic Resistance in New Klebsiella Pneumoniae Clones Emerging in South of Italy. BMC Infect. Dis. 2019, 19, 928. [CrossRef]

10. Adams-Sapper, S.; Sergeevna-Selezneva, J.; Tartof, S.; Raphael, E.; Diep, B.A.; Perdreau-Remington, F.; Riley, L.W. Globally Dispersed Mobile Drug-Resistance Genes in Gram-Negative Bacterial Isolates from Patients with Bloodstream Infections in a US Urban General Hospital. J. Med. Microbiol. 2012, 61, 968-974. [CrossRef]

11. Center for Disease Control and Prevention. Antibiotic Resistance Threats in the United States; Center for Disease Control and Prevention: Atlanta, GA, USA, 2013.

12. Berglund, B. Environmental Dissemination of Antibiotic Resistance Genes and Correlation to Anthropogenic Contamination with Antibiotics. Infect. Ecol. Epidemiol. 2015, 5, 28564. [CrossRef] [PubMed]

13. Davies, J.; Davies, D. Origins and Evolution of Antibiotic Resistance. Microbiol. Mol. Biol. Rev. 2010, 74, 417-433. [CrossRef]

14. Woodford, N.; Wareham, D.W.; Guerra, B.; Teale, C. Carbapenemase-Producing Enterobacteriaceae and Non-Enterobacteriaceae from Animals and the Environment: An Emerging Public Health Risk of Our Own Making? J. Antimicrob. Chemother. 2014, 69, 287-291. [CrossRef]

15. Czekalski, N.; Sigdel, R.; Birtel, J.; Matthews, B.; Bürgmann, H. Does Human Activity Impact the Natural Antibiotic Resistance Background? Abundance of Antibiotic Resistance Genes in 21 Swiss Lakes. Environ. Int. 2015, 81, 45-55. [CrossRef] [PubMed]

16. Raphael, E.; Wong, L.K.; Riley, L.W. Extended-Spectrum Beta-Lactamase Gene Sequences in Gram-Negative Saprophytes on Retail Organic and Nonorganic Spinach. Appl. Environ. Microbiol. 2011, 77, 1601-1607. [CrossRef]

17. Matyar, F.; Kaya, A.; Dinçer, S. Antibacterial Agents and Heavy Metal Resistance in Gram-Negative Bacteria Isolated from Seawater, Shrimp and Sediment in Iskenderun Bay, Turkey. Sci. Total Environ. 2008, 407, 279-285. [CrossRef]

18. Griffin, D.W.; Banks, K.; Gregg, K.; Shedler, S.; Walker, B.K. Antibiotic Resistance in Marine Microbial Communities Proximal to a Florida Sewage Outfall System. Antibiotics 2020, 118. [CrossRef] [PubMed] 
19. Tacão, M.; Correia, A.; Henriques, I.S. Low Prevalence of Carbapenem-Resistant Bacteria in River Water: Resistance Is Mostly Related to Intrinsic Mechanisms. Microb. Drug Resist. 2015, 21, 497-506. [CrossRef] [PubMed]

20. Bush, K.; Bradford, P.A. $\beta$-Lactams and $\beta$-Lactamase Inhibitors: An Overview. Cold Spring Harb. Perspect. Med. 2016, 6, a025247. [CrossRef]

21. Bush, K. Past and Present Perspectives on $\beta$-Lactamases. Antimicrob. Agents Chemother. 2018, 62, e01076-18. [CrossRef]

22. Adams-Sapper, S.; Diep, B.A.; Perdreau-Remington, F.; Riley, L.W. Clonal Composition and Community Clustering of Drug-Susceptible and -Resistant Escherichia Coli Isolates from Bloodstream Infections. Antimicrob. Agents Chemother. 2013, 57, 490-497. [CrossRef]

23. Papp-Wallace, K.M.; Endimiani, A.; Taracila, M.A.; Bonomo, R.A. Carbapenems: Past, Present, and Future. Antimicrob. Agents Chemother. 2011, 55, 4943-4960. [CrossRef] [PubMed]

24. Nordmann, P.; Dortet, L.; Poirel, L. Carbapenem Resistance in Enterobacteriaceae: Here Is the Storm! Trends Mol. Med. 2012, 18, 263-272. [CrossRef] [PubMed]

25. Scotta, C.; Juan, C.; Cabot, G.; Oliver, A.; Lalucat, J.; Bennasar, A.; Albertí, S. Environmental Microbiota Represents a Natural Reservoir for Dissemination of Clinically Relevant Metallo- $\beta$-Lactamases. Antimicrob. Agents Chemother. 2011, 55, 5376-5379. [CrossRef] [PubMed]

26. Montezzi, L.F.; Campana, E.H.; Corrêa, L.L.; Justo, L.H.; Paschoal, R.P.; Da Silva, I.L.V.D.; Souza, M.D.C.M.; Drolshagen, M.; Picão, R.C. Occurrence of Carbapenemase-Producing Bacteria in Coastal Recreational Waters. Int. J. Antimicrob. Agents 2015, 45, 174-177. [CrossRef]

27. Lu, S.Y.; Zhang, Y.L.; Geng, S.N.; Li, T.Y.; Ye, Z.M.; Zhang, D.S.; Zou, F.; Zhou, H.W. High Diversity of Extended-Spectrum Beta-Lactamase-Producing Bacteria in an Urban River Sediment Habitat. Appl. Environ. Microbiol. 2010, 76, 5972-5976. [CrossRef] [PubMed]

28. Novick, E.; Senn, D.B. External Nutrient Loads to San Francisco Bay; San Francisco Estuary Institute: Richmond, CA, USA, 2014.

29. Seto, E.Y.; Konnan, J.; Olivieri, A.W.; Danielson, R.E.; Gray, D.M.D. A Quantitative Microbial Risk Assessment of Wastewater Treatment Plant Blending: Case Study in San Francisco Bay. Environ. Sci. Water Res. Technol. 2015, 2, 134-145. [CrossRef]

30. Trowbridge, P.R.; Davis, J.A.; Mumley, T.; Taberski, K.; Feger, N.; Valiela, L.; Ervin, J.; Arsem, N.; Olivieri, A.; Carroll, P.; et al. The Regional Monitoring Program for Water Quality in San Francisco Bay, California, USA: Science in Support of Managing Water Quality. Reg. Stud. Mar. Sci. 2016, 4, 21-33. [CrossRef]

31. Shellenbarger, G.G.; Athearn, N.D.; Takekawa, J.Y.; Boehm, A.B. Fecal Indicator Bacteria and Salmonella in Ponds Managed as Bird Habitat, San Francisco Bay, California, USA. Water Res. 2008, 42, 2921-2930. [CrossRef]

32. Heal the Bay. 2018-2019 Beach Report Card; Heal the Bay: Santa Monica, CA, USA, 2019.

33. San Francisco Estuary Partnership. The State of the Estuary 2015; San Francisco Estuary Partnership: Oakland, CA, USA, 2015.

34. Picão, R.C.; Cardoso, J.P.; Campana, E.H.; Nicoletti, A.G.; Petrolini, F.V.B.; Assis, D.M.; Juliano, L.; Gales, A.C. The Route of Antimicrobial Resistance from the Hospital Effluent to the Environment: Focus on the Occurrence of KPC-Producing Aeromonas Spp. and Enterobacteriaceae in Sewage. Diagn. Microbiol. Infect. Dis. 2013, 76, 80-85. [CrossRef]

35. Wang, Z.; Zhang, X.-X.; Huang, K.; Miao, Y.; Shi, P.; Liu, B.; Long, C.; Li, A. Metagenomic Profiling of Antibiotic Resistance Genes and Mobile Genetic Elements in a Tannery Wastewater Treatment Plant. PLoS ONE 2013, 8, e76079. [CrossRef] [PubMed]

36. Yee, D.; Wong, A.; Shimabuku, I.; Trowbridge, P. Characterization of Sediment Contamination in Central Bay Margin Areas; San Francisco Estuary Institute: Richmond, CA, USA, 2017.

37. Baker-Austin, C.; Stockley, L.; Rangdale, R.; Martinez-Urtaza, J. Environmental Occurrence and Clinical Impact of Vibrio Vulnificus and Vibrio Parahaemolyticus: A European Perspective. Environ. Microbiol. Rep. 2010, 7-18. [CrossRef] [PubMed]

38. Janda, J.M.; Abbott, S.L. The Genus Shewanella: From the Briny Depths below to Human Pathogen. Crit. Rev. Microbiol. 2014, 40, 293-312. [CrossRef] [PubMed]

39. Holt, H.M.; Gahrn-Hansen, B.; Bruun, B. Shewanella Algae and Shewanella Putrefaciens: Clinical and Microbiological Characteristics. Clin. Microbiol. Infect. 2005, 11, 347-352. [CrossRef] 
40. Maravić, A.; Skočibušić, M.; Šamanić, I.; Fredotović, Ž.; Cvjetan, S.; Jutronić, M.; Puizina, J. Aeromonas Spp. Simultaneously Harbouring BlaCTX-M-15, BlaSHV-12, BlaPER-1 and BlaFOX-2, in Wild-Growing Mediterranean Mussel (Mytilus Galloprovincialis) from Adriatic Sea, Croatia. Int. J. Food Microbiol. 2013, 166, 301-308. [CrossRef]

41. Parkins, M.D.; Gregson, D.B.; Pitout, J.D.D.; Ross, T.; Laupland, K.B. Population-Based Study of the Epidemiology and the Risk Factors for Pseudomonas Aeruginosa Bloodstream Infection. Infection 2010, 38, 25-32. [CrossRef]

42. Poirel, L.; Héritier, C.; Nordmann, P. Chromosome-Encoded Ambler Class D $\beta$-Lactamase of Shewanella Oneidensis as a Progenitor of Carbapenem-Hydrolyzing Oxacillinase. Antimicrob. Agents Chemother. 2004, 48, 348-351. [CrossRef]

43. Pellegrini, C.; Mercuri, P.S.; Celenza, G.; Galleni, M.; Segatore, B.; Sacchetti, E.; Volpe, R.; Amicosante, G.; Perilli, M. Identification of BlaIMP-22 in Pseudomonas Spp. in Urban Wastewater and Nosocomial Environments: Biochemical Characterization of a New IMP Metallo-Enzyme Variant and Its Genetic Location. J. Antimicrob. Chemother. 2009, 63, 901-908. [CrossRef]

44. Rossolini, G.M.; Condemi, M.A.; Pantanella, F.; Docquier, J.D.; Amicosante, G.; Thaller, M.C. Metallo- $\beta$-Lactamase Producers in Environmental Microbiota: New Molecular Class B Enzyme in Janthinobacterium Lividum. Antimicrob. Agents Chemother. 2001, 45, 837-844. [CrossRef]

45. Shaw, K.S.; Rosenberg Goldstein, R.E.; He, X.; Jacobs, J.M.; Crump, B.C.; Sapkota, A.R. Antimicrobial Susceptibility of Vibrio Vulnificus and Vibrio Parahaemolyticus Recovered from Recreational and Commercial Areas of Chesapeake Bay and Maryland Coastal Bays. PLoS ONE 2014, 9, e89616. [CrossRef] [PubMed]

46. Héritier, C.; Poirel, L.; Nordmann, P. Genetic and Biochemical Characterization of a Chromosome-Encoded Carbapenem-Hydrolyzing Ambler Class D $\beta$-Lactamase from Shewanella Algae. Antimicrob. Agents Chemother. 2004, 48, 1670-1675. [CrossRef] [PubMed]

47. Girlich, D.; Poirel, L.; Nordmann, P. Novel Ambler Class A Carbapenem-Hydrolyzing $\beta$-Lactamase from a Pseudomonas Fluorescens Isolate from the Seine River, Paris, France. Antimicrob. Agents Chemother. 2010, 54, 328-332. [CrossRef] [PubMed]

48. Quinteira, S.; Ferreira, H.; Peixe, L. First Isolation of BlaVIM-2 in an Environmental Isolate of Pseudomonas Pseudoalcaligenes. Antimicrob. Agents Chemother. 2005, 49, 2140-2141. [CrossRef] [PubMed]

49. Deng, Y.; Bao, X.; Ji, L.; Chen, L.; Liu, J.; Miao, J.; Chen, D.; Bian, H.; Li, Y.; Yu, G. Resistance Integrons: Class 1, 2 and 3 Integrons. Ann. Clin. Microbiol. Antimicrob. 2015, 14, 45. [CrossRef]

50. Stevens, D.L., Jr.; Olsen, A.R. Spatially Balanced Sampling of Natural Resources. J. Am. Stat. Assoc. 2004, 99, 262-278. [CrossRef]

51. SFEI. Regional Monitoring Program for Water Quality in San Francisco Bay 2015 Bay Margins Sediment Study Cruise Plan; San Francisco Estuary Institute: Richmond, CA, USA, 2015.

52. Coastal Contamination \& Research. Contaminant Concentrations in Central Bay Margins Sediment Cruise Report; Coastal Contamination \& Research: Moss Landing, CA, USA, 2015.

53. CLSI. M100-S25 Performance Standards for Antimicrobial Susceptibility Testing; Twenty-Fifth Informational Supplement; Clinical and Laboratory Standards Institute: Wayne, PA, USA, 2015.

54. Dallenne, C.; da Costa, A.; Decré, D.; Favier, C.; Arlet, G. Development of a Set of Multiplex PCR Assays for the Detection of Genes Encoding Important $\beta$-Lactamases in Enterobacteriaceae. J. Antimicrob. Chemother. 2010, 65, 490-495. [CrossRef]

(C) 2020 by the authors. Licensee MDPI, Basel, Switzerland. This article is an open access article distributed under the terms and conditions of the Creative Commons Attribution (CC BY) license (http://creativecommons.org/licenses/by/4.0/). 